\title{
TEKS KLASIK SEBAGAI SUMBER PENGEMBANGAN LEKSIKOGRAFI MINANGKABAU
}

\section{CLASSIC TEXT AS MINANGKABAU LEXICOGRAPHY SOURCES}

\author{
Rona Almos ${ }^{1}$, Pramono $^{2}$, Herry Nur Hidayat ${ }^{3}$, Seswita $^{4}$ \\ Fakultas Ilmu Budaya Universitas
}

\begin{abstract}
The extinction of regional languages is a phenomenon that needs to be examined and addressed seriously and wisely. Minangkabau language is also feared to be extinct. The Minangkabau language has undergone a change that occurs in the direction of reducing vocabulary. Classic vocabulary, for example, has been replaced by a new vocabulary and even completely disappeared.

This study will specifically find out the kinds of Minangkabau classical texts originating from text edits. Data sources were obtained from the results of research on philology and folklore, namely the edits of manuscripts and folklore documentation. The Lexicon of Minangkabau classical texts in this paper are grouped into three groups, namely, nouns, verbs, and adjectives.
\end{abstract}

Keywords: classical text, Minangkabau, vocabulary, manuscript

\section{PENDAHULUAN}

Kepunahan bahasa-bahasa daerah merupakan fenomena yang perlu dicermati dan disikapi secara serius dan bijaksana. Tidak hanya bahasa-bahasa daerah lainnya di Indonesia, Bahasa Minangkabau juga dikhawatirkan akan mengalami kepunahan. Pada saat ini, kalaupun tidak mengarah pada kepunahan, Bahasa Minangkabau sudah mengalami proses perubahan. Perubahan tersebut dapat kita lihat pada pengurangan kosakata. Kosakata klasik, misalnya, telah tergantikan oleh kosa kata baru dan bahkan hilang sama sekali.

Bahasa Minangkabau merupakan bahasa daerah yang memiliki kekayaan kosa kata, idiom, frase, dan pepatah petitih. Namun, dalam dasawarsa terakhir sudah banyak ditinggalkan (tidak digunakan lagi) oleh masyarakat Minangkabau.

Salah satu penyebab dari permasalahan ini adalah faktor alamiah dan non-alamiah. Faktor alamiahberupa bencana alam, pengaruh bahasa mayoritas, komunitas bahasa yang bilingual atau multilingual, pengaruh globalisasi, migrasi, perkawinan antaretnik - tidak dapat dihindari, maka kurangnya penghargaan terhadap bahasa daerah, kurangnya intensitas pemakaian bahasa daerah, pengaruh faktor ekonomi, dan pengaruh pemakaian bahasa Indonesia merupakan faktor non-alamiah yang dapat disiasati (Tondo, 2009).

Salah satu sumber bahasa daerah asli adalah manuskrip. Pengetahuan dan pengenalan kosa kata dalam manuskrip diharapkan dapat menghidupkan kembali bahasa daerah yang hampir hilang. Usaha ini telah banyak dilakukan, antara lain pengumpulan dan penyusunan bibliografi kosa kata bahasa daerah di Filipina (Bolton \& Butler, 2004; Rodríguez, 2014), Olga (Weijers, 1989) telah melakukan kajian leksikografi medieval, bahasa Perancis (Rothwell, 2002), dan masih banyak lagi. 


\section{KERANGKA PEMIKIRAN DAN METODOLOGI}

Leksikologi, yakni ilmu yang mempelajari seluk-beluk kata, menyelidiki kosa kata suatu bahasa, baik mengenai pemakaian maupun maknanya seperti yang dipakai oleh masyarakat bahasa bersangkutan (Usman, 1979). Dalam leksikologi butir-butir leksikal suatu bahan dikaji asal-usulnya, bentuk dan pembentukannya, maknanya, penggunaannya aspek bunyi dan ejaannya, serta aspek lainnya. Lalu kalau kemudian hasil kajian leksikologi ini ditulis dan disusun secara alfabet, maka bidang kegiatannya sudah termasuk dalam kegiatan leksikografi (Rona \& Pramono, 2015).

Adapun semantik merupakan sistem dan penyelidikan makna dan arti dalam suatu bahasa atau bahasa pada umumnya (Kridalaksana, 2008). Mempelajari makna pada hakikatnya mempelajari bagaimana setiap pemakai bahasa dalam suatu masyarakat bahasa saling mengerti (Djajasudarma, 1993).

Oleh karena objek kajian adalah naskah klasik, maka studi ini tidak bisa lepas dari filologi. Filologi berasal dari bahasa Yunani philologia 'kegemaran berbicang-bincang'. Filologi Selama ini dikenal sebagai ilmu yang berhubungan dengan karya masa lampau yang berupa tulisan. Studi terhadap karya tulis masa lampau dilakukan karena adanya ungkapan bahwa dalam peninggalan tulisan terkandung nilai-nilai yang masih relevan dengan kehidupan masa kini. Sebagai hasil budaya masa lampau, peninggalan tulisan perlu dipahami dalam konteks masyarakat yang melahirkannya. Pengetahuan tentang berbagai konvensi yang hidup dalam masyarakat yang melatarbelakangi penciptaannya mempunyai peran yang besar bagi upaya memahami kandungan isinya (Baried, Sutrisno, Chamamah-Soeratno, Sawu, \& Istanti, 1994).

Kerja filologi kini tidak hanya sekadar menemukan manuskrip asli atau varian yang mendekati aslinya. Filolog telah mengembangkan keilmuan dengan mengadopsi bidang ilmu lain sehingga manuskrip tidak hanya menjadi bahan bacaan belaka. Manuskrip bisa menjadi sumber pengetahuan persenjataan (Pramono, Hasbullah, \& Hidayat, 2015), pengetahuan pengobatan (Danang Susena et al., 2013; Rona \& Pramono, 2015), kebahasaan (Pramono, Yusuf, \& Hidayat, 2018), bahkan sebagai sumber desain ragam hias kain (Nurhayati, 2014; Rudiyanto, 2014).

Kajian naskah-naskah kuno Minangkabau yang mengandung teks klasik masih minim dilakukan. Menurut Suryadi (Suryadi, 2006), di sinilah tantangan intelektual Minangkabau, khususnya ahli bahasa dan perkamusan. Kekayaan bahasa Minangkabau itu harus diselamatkan; dicatat di atas kertas. Jika kita tidak bertindak cepat, dengan mencatat seluruh kosa kata, frase, idiom, dan pepatah-petitih Minangkabau itu, terutama sekali yang telah arkais dan menjadi klasik, maka dapat dipastikan sedikit jejak yang akan tertinggal di masa depan. Berdasarkan uraian di atas maka, penyusunan kamus Minangkabau harus dilakukan untuk mengungkap unsur-unsur bahasa Minangkabau klasik.

Kajian leksikografi yang berkenaan dengan kategorisasi kosa kata dilakukan oleh Ramli (Ramli, 2015) dengan kajian leksikografi Arab dan dapat menjelaskan istilah dan nama tumbuh-tumbuhan dalam Al-Qur'an AlKarim. Kosa kata tumbuh-tumbuhan digunakan dalam empat jenis gaya bahasa dalam Al-Qur'an Al-Karim, Penggunaan istilah tumbuh-tumbuhan dalam gaya bahasa ini menampilkan keindahan gaya bahasa Al-Qur'an AlKarim bagi menyampaikan pesan Ilahi kepada manusia. Teja (Teja, Sumarlam, \& Satoto, 2017) melakukan kajian terhadap kekhasan bunyi bahasa dan bentuk arkais dalam Serat Ciptan Saben Esuk yang menyimpulkan asonansi dalam serat tersebut termasuk dalam kata arkais. Dinamika bahasa Jawa Kuna pada masyarakat Bali dikaji oleh Erawati (Erawati, 2015) yang menemukan bahasa Jawa Kuna masih digunakan terutama pada pertunjukan dan upacara keagamaan. 


\section{Jurnal Elektronik WACANA ETNIK - Vol 6 No 2 Oktober 2017, (67 - 72)}

p ISSN 2089-8746, e ISSN 2302-7142

\section{TEMUAN DAN PEMBAHASAN}

Setelah dicermati dan dipahami kelas kata kosa kata yang ditemukan dalam teks klasik bahasa Minangkabau dapat dikelompokkan menjadi 1) nomina, 2) verba dan 3) adjektiva. Masing-masing pengelompokan tersebut diuraikan sebagai berikut.

\section{NOMINA}

Nomina adalah kelas kata yang dalam bahasa Indonesia ditandai oleh tidak dapatnya bergabung dengan kata tidak, misalnya gelas adalah nomina karena tidak mungkin dikatakan tidak gelas. Biasanya dapat berfungsi sebagai subjek atau objek dari klausa.
a. abuh $[$ abuh $]$
sayur; daun-daunan, tumbuh-tumbuhan, polongan dan sebagainya yang dapat dimasak.

b. labeh $[l a b s h]$

kacang; tanaman yang biasanya ditanam di lading, berbuah polong (macamnya sangat banyak)

c. lacak [laca?]

minuman keras; minuman yang memabukkan atau minuman keras seperti bir, tuak, anggur.

d. laciah [laciah]

hamba; budak; jongos; orang gajian

e. ladan [ladan]

petai; dalam bahasa latin disebut juga dengan parkia speciosa merupakan pohon yang ridang, buahnya bulat, biasanya dimakan sebagai sayur atau lalap dan berbau kurang sedap.

f. rendang [renday]

ekspresi; air muka

g. ruman $[$ ruman $]$

tangkai padi

h. alang [alay]

hadiah, pemberian.

i. $\quad$ atan $[$ atan $]$

alu, alat yang digunakan untuk menumbuk padi yang terbuat dari kayu; atan

j. antiak [antia?]

panggilan kepada kakak laki-laki

k. sangku [sangku]

mangkuk yang terbuat dari kuningan.

1. sonok [sono?]

pisang, ubi atau buah-buahan lainnya yang dimasak dengan campuran santan dan gula hitam.

\section{VERBA}

Verba adalah kata yang mengambarkan proses, perbuatan, atau keadaan.

a. $\operatorname{abok}[$ abo?]

memegang secara tiba-tiba atau mendekap secara tiba-tiba.

b. labang [labay] 


\section{Jurnal Elektronik WACANA ETNIK - Vol 6 No 2 Oktober 2017, (67 - 72) \\ p ISSN 2089-8746, e ISSN 2302-7142}

tempa; menempa

c. labua [labua]

telanjur; terlewat dari batas yang sudah ditentukan .

d. loco $[$ loco $]$

1. bangun; bangkit; belum tidur

2. mulain insaf atau mulai sadar

e. puli $[p u l i]$

pukul; memukul

f. rundak [runda?]

bekerja dengan tiada menimbang terlebih dahulu.

g. $\operatorname{moda}[\bmod a]$

mati dengan tidak disembelih

h. muntu [muntu]

tidak mau berbicara dengan orang lain karena ia marah atau benci kepada orang tersebut.

i. $\quad$ antau $[$ antau $]$

lempar; buang jauh-jauh

j. $\quad$ pikau $[$ pikau]

berteriak dengan sangat keras

\section{ADJEKTIVA}

Adjektiva adalah kata yang menerangkan nomina (kata benda) dan secara umum dapat bergabung dengan kata lebih dan sangat.
a. abok [abo?]
lembut, halus, agak lunak (tidak keras)
b. $a b u[a b u]$
1. bohong; tidak sesuai dengan hal yang sebenarnya.
2. tidak pernah
c. $\operatorname{acak}[\operatorname{aca}$ ?]
congkak; sombong; angkuh; pongah; jumawa
d. labi [labi]
penyakit perut yang biasa dialami oleh perempuan setiap datang bulan.
e. raduik [radui?]
iba; terharu dan kasihan.
f. santoho [santoho]
1. malu; rasa terhina dan rendah
2. segan melakukan sesuatu karena adanya rasa takut, rasa hormat dan sebagainya.
g. adua [adua]
amat banyak
h. aguang [aguay]
penangis; mudah atau suka menangis; cengeng
i. ajik [aji?] 


\section{Jurnal Elektronik WACANA ETNIK - Vol 6 No 2 Oktober 2017, (67 - 72) \\ p ISSN 2089-8746, e ISSN 2302-7142}

1. kecil;

2. lemah sekali

j. salentong [salentong]

kaku ketika membuat sesuatu

Temuan tersebut di atas bisa menjadi sumber pengayaan kamus bahasa Minangkabau. Di samping itu, penyusunan kamus tersebut adalah salah satu usaha revitalisasi bahasa daerah. Hal ini juga sejalan dengan usaha pengayaan kamus bahasa daerah lain. Kajian leksikografi yang berhubungan dengan kamus telah dilakukan oleh Sudaryanto yang menginventaris kosa kata bahasa Indonesia dan daerah (Sudaryanto, 2017). Sirulhaq (Sirulhaq, Syukri, \& Djafar, 2009) mencoba menyusun konsep untuk pengayaan Kamus Besar Bahasa Indonesia.

\section{PENUTUP}

Berdasarkan uraian di atas dapat di rumuskan bahwa salah satu bentuk kerja pendokumentasian bahasa adalah dengan mengumpulkan dan menyimpan secara apik dan dapat digunakan atau dimanfaat dengan mudah oleh masyarakat awam maka penyusunan kamus harus dilakukan. Leksikon teks klasik Minangkabau dapat dikelompokkan menjadi tiga kelompok yakni, nomina, verba dan adjektiva

\section{REFERENSI}

Baried, S. B., Sutrisno, S., Chamamah-Soeratno, S., Sawu, \& Istanti, K. Z. (1994). Pengantar Teori Filologi. (F. M. Manshur, Sudibyo, \& K. Zachrun, Eds.). Jakarta: Pusat Pembinaan dan Pengembangan Bahasa.

Bolton, K., \& Butler, S. (2004). Dictionaries and the stratification of vocabulary: towards a new lexicography for Philippine English. World Englishes, 23(1), 91-112. https://doi.org/10.1111/j.1467971X.2004.00337.x

Danang Susena, Pramono, Herry Nur Hidayat, Susena, D., Pramono, \& Hidayat, H. N. (2013). Pengobatan Tradisional dalam Naskah-naskah Minangkabau: Inventarisasi Naskah, Teks, dan Analisis Etnomedisin. Wacana Etnik, 4(2), 133-152. Retrieved from http://wacanaetnik.fib.unand.ac.id/index.php/wacanaetnik/article/view/53

Djajasudarma, F. (1993). Sematik 1 Pengantar ke Arah Ilmu Makna. Bandung: Eresco.

Erawati, N. K. R. (2015). Eksistensi dan Dinamika Kosa Kata Bahasa Jawa Kuna pada Masyarakat Bali Masa Kini. Jurnal Kajian Bali (Journal of Bali Studies), 5(1). Retrieved from https://ojs.unud.ac.id/index.php/kajianbali/article/view/15729

Kridalaksana, H. (2008). Kamus Linguistik. Jakarta: Gramedia.

Nurhayati. (2014). Kolaborasi Teknik Batik dengan Iluminasi Naskah Dewa Ruci Pura Mangkunegaran Surakarta. In H. N. Hidayat, Pramono, \& Zuriati (Eds.), Naskah dan Relevansinya dalam Kehidupan Masa Kini. Padang: PSIKM.

Pramono, Hasbullah, W. M. D. W., \& Hidayat, H. N. (2015). MYSTICISM ELEMENTS IN THE USE OF FIREARM TECHNOLOGY IN THE MANUSCRIPT ON FIREARMS. Jurnal Humaniora, 27(3), 373. https://doi.org/10.22146/jh.v27i3.10597

Pramono, Yusuf, M., \& Hidayat, H. N. (2018). BAHASA MELAYU DAN MINANGKABAU DALAM KHAZANAH NASKAH MINANGKABAU. Jurnal Pustaka Budaya, 5(2), 24-35. https://doi.org/10.31849/pb.v5i2.1483

Ramli, S. (2015). Istilah tumbuh-tumbuhan dalam Al-Quran Al-Karim:kajian leksikografi dan analisis Wacana bahasa Arab. Universiti Pendidikan Sultan Idris. Retrieved from http://ir.upsi.edu.my/1278/

Rodríguez, R. F. (2014). Lexicography in the Philippines (1600-1800). Historiographia Linguistica, 41(1), 132. https://doi.org/10.1075/hl.41.1.01 rod

Rona, A., \& Pramono. (2015). Leksikon Etnomedisin dalam Pengobatan Tradisional Minangkabau. Jurnal Arbitrer, 2(1), 44-53. https://doi.org/10.25077/ar.2.1.44-53.2015

Rothwell, W. (2002). The semantic field of Old French Astele: the pitfalls of the medieval gloss in lexicography. Journal of French Language Studies, 12(2), 203-220. https://doi.org/10.1017/S095926950200025X

Rudiyanto, M. (2014). Dari Iluminasi Naskah-Naskah Minangkabau ke Desain Motif Batik. In H. N. Hidayat, 
Pramono, \& Zuriati (Eds.), Naskah dan Relevansinya dalam Kehidupan Masa Kini. Padang: PSIKM.

Sirulhaq, A., Syukri, M., \& Djafar, S. (2009). Konsep Pemerkayaan Kamus Besar Bahasa Indonesia Dan Politik Bahasa Dalam Dinamika Global. In Bahasa dan Sastra Indonesia dalam Konteks Global KONSEP. Jember: PS PBSI FKIP Universitas Jember.

Sudaryanto, S. (2017). Inventarisasi Kosakata Daerah dalam Bahasa Indonesia Sebagai Sarana Konservasi Bahasa: Kajian Leksikologi. In Proceeding 6th University Research Colloquium 2017: Seri Pendidikan (pp. 217-226). Magelang. Retrieved from http://journal.ummgl.ac.id/index.php/urecol/article/view/1488

Suryadi. (2006, April 30). Menyelamatkan Kekayaan Bahasa Minangkabau: Tantangan Ahli Bahasa dan Perkamusan. Padang Expres.

Teja, B. A., Sumarlam, S., \& Satoto, S. (2017). KEKHASAN BUNYI BAHASA DAN BENTUK KATA ARKAIS DI DALAM SERAT CIPTAN SABEN ESUK KARYA R. M PARTAWIRAYA DAN R. PRAWIRAHARJA. PRASASTI: Journal of Linguistics, 2(1), 21. https://doi.org/10.20961/prasasti.v2i1.1410

Tondo, F. H. (2009). Kepunahan Bahasa-Bahasa Daerah: Faktor Penyebab dan Implikasi Etnolinguistis. Jurnal Masyarakat \& Budaya, 11(2).

Usman, A. H. (1979). Pengantar Ilmu Kosa Kata (Leksikologi). Padang: FPBS-IKIP.

Weijers, O. (1989). Lexicography in the Middle Ages. Viator, 20, 139-154. https://doi.org/10.1484/J.VIATOR.2.301351 